\title{
Penentuan Tingkat Kerentanan Pulau Guraici Berdasarkan Kapasitas Adaptif Ekosistem Pesisir
}

\author{
Riyadi Subur ${ }^{1}$ \\ ${ }^{1}$ Manajemen Sumberdaya Perairan FPIK-Universitas Khairun \\ Kampus 2 Gambesi. Jln. Raya Pertamina, Ternate. Maluku Utara \\ Email: riyadisubur58@gmail.com
}

\begin{abstract}
Abstrak
Pulau Guraici tergolong pulau sangat kecil, dengan luas saat ini $\pm 0,59$ hektar, luas daratan pulau ini terus mengalami degradasi sebagai akibat hilangnya ekosistem pesisir utama seperti terumbu karang, mangrove, lamun, sehingga kerentanan dari pulau tersebut terus meningkat. Penelitian ini bertujuan menilai serta menentukan tingkat kerentanan pulau Guraici berdasarkan Kapasitas Adaptif ekosistem pesisir pula tersebut. Penelitian ini dilakukan dengan mengukur kapasitas adaptasi ekosistem terumbu karang, mangrove dan Lamun (seagrass). Hasil penelitian ini menunjukkan bahwa nilai kapasitas Adaptif ekosistem pesisir yang ditemukan di pulau tersebut yaitu 0,34, dengan kategori "sangat rendah", yang berarati bahwa pulau Guraici memiliki kerentanan sangat tinggi.
\end{abstract}

Kata kunci : Kerentanan, Kapasitas Adaptif, Ekosistem Pesisir.

\begin{abstract}
Guraici Island is considered a very small island, with an area of \pm 0.59 hectares, the area of the island continues to degrade as a result of the loss of major coastal ecosystems such as coral reefs, mangroves, seagrasses, so the vulnerability of the island continues to increase. This study propouse to assess and determine the vulnerability of Guraici island based on Adaptive Capacity of the coastal ecosystem. This research was conducted by measuring the adaptation capacity of coral reef ecosystem, mangrove and seagrass. The results of this study indicate that the Adaptif capacity value of coastal ecosystems found on the island is 0.37, with the category "very low", which means that Guraici island has very high vulnerability.
\end{abstract}

Keywords: Vulnerability, Adaptive Capacity, Coastal Ecosystem. 


\section{PENDAHULUAN}

\subsection{Latar Belakang}

Kerentanan merupakan salah satu ciri penting pada pulau-pulau kecil dan wilayah pesisirnya juga teridentifikasi sebagai daerah paling rentan terhadap perubahan iklim, misalnya sebagai akibat peristiwa ekstrim dan kenaikan permukaan laut Briguglio (1995); Mimura (1999); Lewis (2009); (Bunce 2009). Semua permasalahan yang terjadi pada wilaya pesisir tersebut dapat mengakibatkan menurunnya kualitas lingkungan pulau-pulau kecil. Kualitas lingkungan yang rendah akan memberikan dampak pada meningkatnya potensi kerusakan ekosistem maupun sumberdaya alam di pulau-pulau kecil. Namun disisi lain, ekosistem dan sumberdaya alam yang tersedia memberikan manfaat yang sangat penting bagi manusia atau yang biasa digambarkan sebagai pendukung kehidupan, penyedia bahan dan energi serta sebagai penyerap limbah (Gossling 1999).

Pulau Guraici sebagai salah satu pulau sangat kecil saat ini mengalami degradasi luas daratan yang signifikan, hasil penelitian tahun 2004 menyebutkan bahwa luas daratan pulau Guraici saat itu seluas 1,6 ha (DKP-Malut 2004), selanjutnya penelitian yang dilakukan tahun 2011, menunjukkan bahwa luas daratan pulau Guraici tersisa sekitar 0,59 ha, yang berarti terjadi degradasi luas daratan pulau Guraici sebanyak 1,1 hektar dalam waktu sekitar 12 tahun. Kondisi tersebut dapat terjadi karena pulau tersebut merupakan pulau primadona diantara pulau lainnya, bagi para pengunjung yang pada saat tertentu datang dalam jumlah besar (rombongan) seperti kegiatan yang diselenggarakan oleh pemerintah Propinsi Maluku Utara atau pemerintah Kabupanten, merupakan salah satu pemicu terjadinya degradasi daratan pulau Guraici.

Keberadaan ekosistem pesisir penting di pulau kecil seperti Terumbu karang, Mangrove dan Lamun (Seagrass), secara alamiah dapat meningkat kapasitas adaptif dan pada saat yang bersamaan menurunkan kerentanan suatu pulau kecil. Namun keberadaan ekosistem tersebut, turut terdegradasi, sehingga ditemukan dalam jumlah yang terbatas.

Analisis kerentanan pulau Guraici, dilakukan dengan mengkaji kapasitas adaptif ekosistem terumbu karang, ekosistem mangrove dan ekosistem lamun ketiganya dipilih karena merupakan ekosistem utama yang umumnya ditemukan di pulau-pulau kecil.

Berdasarkan pada uraian sebelumnya, maka beberapa permasalahan yang perlu di jawab dalam penelitian di pulau Guraici yaitu "bagaimana tingkat kerentanan pulau Guraici ditinjau dari aspek kapasitas adaptif ekosistem terumbu karang, mangrove dan lamun".

\section{BAHAN DAN METODE}

\subsection{Tempat dan Waktu Penelitian}

Penelitian ini dilakukan di pulau Guraici Kecamatan Kayoa, Provinsi Maluku Utara.

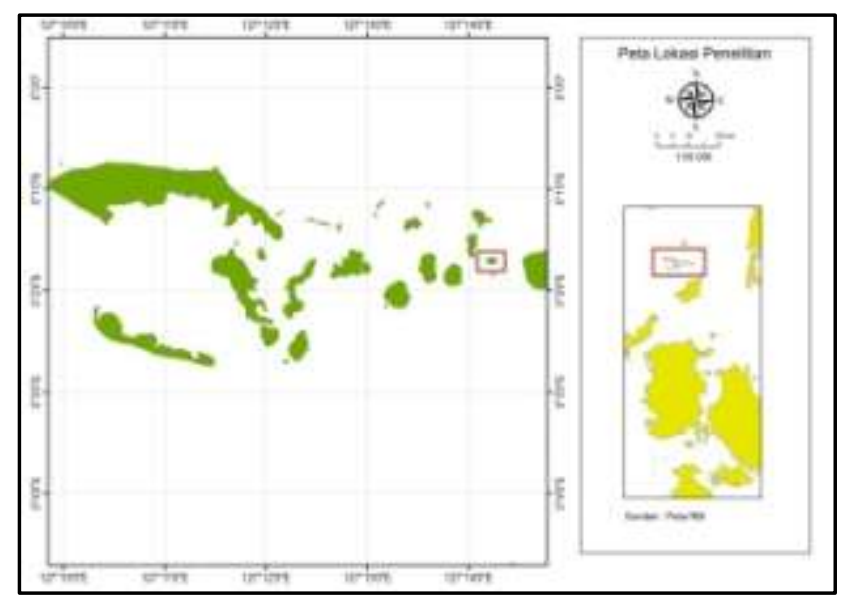

Gambar 1. Peta Lokasi Penelitian

\subsection{Bahan dan Alat}

Bahan dan alat yang digunakan dalam penelitian ini meliputi peta lokasi, perlengkapan tulis menulis, Global Positioning System (GPS), peralatan sampling terhadap ekosistem terumbu karang, 
ekosistem mangrove dan ekosistem lamun serta peralatan selam maupun peralatan lainnya yang mendukung dalam pengambilan data di lapangan.

\subsection{Pengumpulan Data Kapasitas Adaptif}

Pengumpulan data kapasitas adaptif dimulai dengan pengambilan data pada tiga komponen ekosistem pesisir, meliputi ekosistem terumbu karang, ekosistem mangrove dan ekosistem lamun. Pengumpulan data pada ketiga ekositem tersebut dilakukan langsung di lapangan (insitu), maupun melalui bantuan analisis sistem informasi geografis (SIG), dalam proses pengukuran tertentu.

Salah satu langkah penting dalam menghitung dan menilai kapasitas adaptif ekologi dalam di pulau Guraici adalah penentuan skor/ skla setiap parameter kedalam nilai-nilai tertentu, sehingga setiap nilai tersebut dinyatakan sebagai nilai skor dari suatu parameter. Penelitian ini menggunakan metode penskalaan yang dikemukakan oleh Doukakis (2005), sebagaimana yang ditampilkan pada Tabel berikut ini.
Tabel 1. Contoh penentuan Skala

\begin{tabular}{ccccc}
\hline \multicolumn{5}{c}{ Skala/ Skor } \\
\hline 1 & 2 & 3 & 4 & 5 \\
\hline $\begin{array}{c}\text { Sangat } \\
\text { Rendah }\end{array}$ & Rendah & Sedang & Tinggi & $\begin{array}{c}\text { Sangat } \\
\text { Tinggi }\end{array}$ \\
\hline
\end{tabular}

Sumber : Doukakis (2005).

\subsubsection{Kapasitas Adaptif Ekosistem Terumbu Karang}

Kapasitas adaptif ekosistem terumbu karang, dihutung dan dianalisis dengan menggunakan tujuh (7) parameter, yang meliputi; (1) Perhitungan Indeks Dimensi Terumbu Karang (IDTK), (2) Tutupan karang (\%), (3) Dominasi lifeform, (4) Jumlah jenis lifeform, (5) Jumlah spesies ikan karang, (6) Kedalaman terumbu karang, dan (7) Jarak ekosistem terumbu karang dari pemukiman penduduk. Kriteria penilaian kapasitas adaptif ekosistem terumbu karang ditampilkan pada Tabel 2.

Tabel 2. Kriteria Penilaian Kapasitas Ekosistem Terumbu Karang.

\begin{tabular}{|c|c|c|c|c|c|c|}
\hline \multirow{3}{*}{ Parameter } & \multirow{3}{*}{ Bobot } & \multicolumn{5}{|c|}{ Skala/ Skor } \\
\hline & & 1 & 2 & 3 & 4 & 5 \\
\hline & & Sangat Rendah & Rendah & Sedang & Tinggi & Sangat Tinggi \\
\hline $\begin{array}{l}\text { Indeks Dimensi Terumbu Karang } \\
(I D T K)\end{array}$ & 5 & $0,0 \leq \mathrm{IDTK} \leq 0,4$ & $0,4<\mathrm{IDTK} \leq 0,8$ & $0,8<\mathrm{IDTK} \leq 1,2$ & $0,2<\mathrm{IDTK} \leq 0,6$ & $1,6-2,0$ \\
\hline Tutupan karang (\%) & 5 & $0-20$ & $21-40$ & $41-60$ & $61-80$ & $81-100$ \\
\hline Dominasi Lifeform & 5 & $\mathrm{SC}, \mathrm{Ot}$ & $\mathrm{BC}$ & $\mathrm{ACT}, \mathrm{ACD}$ & $\mathrm{CE}$ & $\mathrm{CM}, \mathrm{CS}$ \\
\hline Jumlah Jenis lifeform & 3 & $<4$ & $4-7$ & $7-12$ & $12-15$ & $>15$ \\
\hline Jumlah spesies ikan karang & 3 & $<10$ & $10-<30$ & $30-50$ & $50-80$ & $>80$ \\
\hline $\begin{array}{l}\text { kedalaman terumbu } \\
\text { karang }(\mathrm{m})\end{array}$ & 1 & $<1$ & $>1-5$ & $>5-10$ & $>10-15$ & $>15$ \\
\hline Jarak dari pemukiman penduduk $(\mathrm{km})$ & 1 & $<0,5$ & $>0,5-1$ & $>1-4$ & $>4-5$ & $>5$ \\
\hline
\end{tabular}

Setelah seluruh komponen data pada ekosistem terumbu karang dianalisis, maka proses selanjutnya dilakukan analisis kapasitas adaptif ekosistem terumbu karang pada setiap pulau dalam gugus pulau Guraici. Analisis tersebut dilakukan dengan menggunakan persamaan Subur et al. (2011) sebagai berikut: 


$$
K P T K=\sum\left[\frac{N i}{N_{\text {maks }}}\right] \times 100 \%
$$

Keterangan :

KPTK : Nilai Kapasitas ekosistem terumbu karang

$N_{i} \quad$ : Total nilai parameter hasil pengukuran

$N_{\max }$ : Nilai maksimum parameter pada ekosistem terumbu karang.

Nilai kapasitas ekosistem terumbu karang beradapa pada kisaran antara 0,0-1,0, dengan lima (5) kategori yang terdiri dari

"sangat rendah $(0,0 \leq K P T k \leq 0,2)$ ".

"Rendah $(0,2<K P T k \leq 0,4)$ ".

"Sedang $(0,4<K P T k \leq 0,6)$ ".

"Tinggi $(0,6<K P T k \leq 0,8)$ ".
"Sangat Tinggi $(0,8<K P T k \leq 1,0)$ ".

\subsubsection{Kapasitas Adaptif Ekosistem Mangrove}

Penilaian kapasitas adaptif ekosistem mangrove yang ditemukan pada pulau Guraici, dilakukan dengan mempertimbangkan enam parameter meliputi; (1) perhitungan indeks dimensi mangrove (IDMg), (2) Spesies mangrove dominan, (3) kerapatan (pohon/ ha), (4) Jumlah genera, (5) Tipe substrat, dan (6) Jarak ekosistem mangrove dari pemukiman penduduk. Kriteria penilaian kapasitas adaptif ekosistem mangrove ditampilkan pada Tabel 3.

Tabel 3. Kriteria Penilaian Kapasitas Mangrove

\begin{tabular}{|c|c|c|c|c|c|c|}
\hline \multirow{3}{*}{ Parameter } & \multirow{3}{*}{ Bobo } & \multicolumn{5}{|c|}{ Skala/ Skor } \\
\hline & & 1 & 2 & 3 & 4 & 5 \\
\hline & & Sangat rendah & Rendah & Sedang & Tinggi & Sangat tinggi \\
\hline $\begin{array}{l}\text { Indeks Dimensi } \\
\text { Mangrove (IDMg) }\end{array}$ & 5 & $0,0 \leq \mathrm{IDMg} \leq 0,40$ &, $4<\mathrm{IDMg} \leq 0$ &, $8<\mathrm{IDMg} \leq 1$ & $2<\mathrm{IDMg} \leq 0,6$ & $1,6-2,0$ \\
\hline Spesies Dominan & 5 & $\begin{array}{l}\text { Ceriops / } \\
\text { Nypa }\end{array}$ & Bruguieria & Rhizopora & Soneratia & Avicenia \\
\hline Kerapatan (pohon/ha) & 3 & $<110$ & $110 \leq 330$ & $330 \leq 660$ & $660 \leq 880$ & $\geq 880$ \\
\hline Jumlah genera & 3 & $1-2$ & $3-5$ & $6-7$ & $8-10$ & $11-12$ \\
\hline Tipe substrat & 1 & $\begin{array}{c}\text { Pasir } \\
\text { Berkarang }\end{array}$ & Pasir & $\begin{array}{c}\text { Pasir } \\
\text { Berlumpur }\end{array}$ & $\begin{array}{l}\text { Lumpur } \\
\text { Berpasir }\end{array}$ & Berlumpur \\
\hline $\begin{array}{l}\text { Jarak dari pemukiman } \\
\text { pendududk }(\mathrm{km})\end{array}$ & 1 & $<0,5$ & $>0,5-1$ & $>1-4$ & $>4-5$ & $>5$ \\
\hline
\end{tabular}

Nilai maksimum : 90

Setelah pengukuran dilakukan terhadap komunitas mangrove yang mencakup dimensi ketebalan/ lebar serta dimensi panjang, maka dilakukan perhitungan terhadap nilai indeks dimensi komunitas mangrove. Perhitungan tersebut menggunakan persamaan Subur et al. (2011); Subur (2012) ; Subur et al. (2013) sebagai berikut:

$$
I D M g=\sum\left[\frac{N L}{S L}\right]+\sum\left[\frac{N P}{S P}\right]
$$

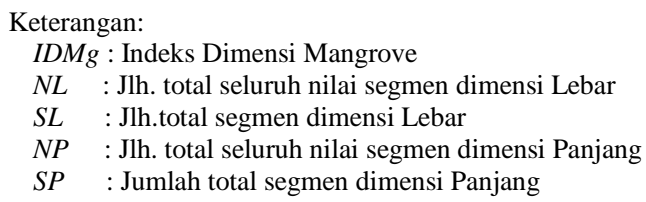

Nila Indeks Dimensi Mangrove (IDMg) berada pada kisaran antara 0.0-2.0, yang terdistribusi kedalam lima kategori yaitu :

"Sangat Rendah $(0,0 \leq I D M g \leq 0,4)$. 
"Rendah $(0,4<I D M g \leq 0,8)$ ".

"Sedang $(0,8<I D M g \leq 1,2)$ ".

“Tinggi $(0,2<I D M g \leq 0,6)$ ".

"Sangat Tinggi $(1,6<I D M g \leq 2,0)$ ".

\subsubsection{Kapasitas Adaptif Ekosistem Lamun}

Kapasitas adaptif ekosistem lamun, dihutung dan dianalisis dengan mempertimbangkan enam (6) parameter, yang terdiri dari (1) Perhitungan Indeks Dimensi Lamun (IDLn), (2) spesies lamun (\%), (3) Persentasi tutupan lamun (\%), (4) Jumlah spesies lamun, (5) Tipe substrat, dan (7) Jarak ekosistem lamun dari pemukiman penduduk. Kriteria penilaian kapasitas adaptif ekosistem mangrove tersebut ditampilkan pada Tabel 4.

Tabel 4. Kriteria Penilaian Kapasitas Lamun

\begin{tabular}{|c|c|c|c|c|c|c|}
\hline \multirow{3}{*}{ Parameter } & \multirow{3}{*}{ Bobot } & \multicolumn{5}{|c|}{ Skala/ Skor } \\
\hline & & 1 & 2 & 3 & 4 & 5 \\
\hline & & Sangat rendah & Rendah & Sedang & Tinggi & Sangat tinggi \\
\hline $\begin{array}{l}\text { Indeks dimensi } \\
\text { Lamun (IDLn) }\end{array}$ & 5 & $0,0 \leq \mathrm{IDLn} \leq 0,4$ & $0,4<\operatorname{IDLn} \leq 0,8$ & $0,8<\mathrm{IDLn} \leq 1,2$ & $0,2<\mathrm{IDLn} \leq 0,6$ & $1,6-, 0$ \\
\hline Spesies Lamun & 5 & Halophila, & $\begin{array}{l}\text { Halodule, } \\
\text { Sryngodium }\end{array}$ & $\begin{array}{c}\text { Cymodocea, } \\
\text { Thalassodendron }\end{array}$ & Thalassia & Enhalus \\
\hline Penutupan (\%) & 3 & $<10$ & $10-29,9$ & $30-59,9$ & $60-79,9$ & $>80$ \\
\hline Jumlah spesies & 3 & $1-2$ & $3-5$ & $6-7$ & $8-10$ & $11-12$ \\
\hline Tipe substrat & 1 & Pasir & $\begin{array}{c}\text { Pasir } \\
\text { Berkarang }\end{array}$ & Pasir Berlumpur & $\begin{array}{l}\text { Lumpur } \\
\text { Berpasir }\end{array}$ & Berlumpur \\
\hline $\begin{array}{l}\text { Jarak dari } \\
\text { pemukiman } \\
\text { penduduk }(\mathrm{km})\end{array}$ & 1 & $<0,5$ & $>0,5-$ & $>1-4$ & $>4-5$ & $>5$ \\
\hline
\end{tabular}

Setelah seluruh komponen data pada ekosistem lamun dianalisis, proses selanjutnya adalah melakukan analisis kapasitas adaptif ekosistem lamun pada setiap pulau dalam gugus pulau Guraici. Analisis tersebut dilakukan dengan menggunakan persamaan Subur et al. (2011) sebagai berikut;

$$
K P L n=\sum\left[\frac{N i}{N_{\text {maks }}}\right] \times 100 \%
$$

Keterangan :

KPLn : Nilai Kapasitas ekosistem lamun pulau

$N_{i} \quad$ : Total nilai parameter hasil pengukuran

$N_{\text {Max }}$ : Nilai maksimum parameter pada ekosistem terumbu karang.
Nilai kapasitas adaptif ekosistem lamun beradapa pada kisaran antara 0,0-1,0, dengan lima (5) kategori yang terdiri dari "sangat rendah $(0,0 \leq K P L n \leq 0,2)$ ". "Rendah $\quad(0,2<K P L n \leq 0,4)$ ". "Sedang $\quad(0,4<K P L n \leq 0,6)$ ". "Tinggi $(0,6<K P L n \leq 0,8)$ ". "Sangat Tinggi $(0,8<K P L n \leq 1,0)$ ".

\section{Analisis Kapasitas Adaptif Eksositem Pesisir}

Analisis Kapasitas Ekosistem Pesisir Dilakukan Dengan Menggunakan Formula yang dikembangkan oleh Subur 2012, sebagai berikut :

$$
K A E=\mathrm{KTrK}+\mathrm{KMg}+\mathrm{KLn}
$$


Keterangan :

$$
\begin{array}{ll}
\mathrm{KAE} & : \text { Kapasitas Adaptif Ekosistem } \\
\mathrm{KtrK} & : \text { Kapasitas Terumbu Karang } \\
\mathrm{KMg} & : \text { Kapasitas Mangrove } \\
\mathrm{KLn} & : \text { Kapasitas Lamun }
\end{array}
$$

Nilai Kapasitas Adaptif Ekosistem Pesisir Berkisar antara 0,0 - 3,0.

\section{Dengan Kriteria :}

$\begin{array}{lll}\text { Sangat Renda } & : & 0,0 \pm 0.6 \\ \text { Rendah } & : & 0,6-1,2 \\ \text { Sedang } & : & 1,2-<1,8 \\ \text { Tinngi } & : & 1,8-<2,4 \\ \text { Sangat Tinggi } & : & 2,4-3,0\end{array}$

\section{HASIL DAN PEMBAHASAN}

\subsection{Pengukuran Kapasitas Adaptif Ekosistem Terumbu Karang}

Untuk mendapatkan nilai kapasitas terumbu karang pada pulau Guraici, terlebih dulu dilakukan pengukuran-pengukuran terhadap parameter-parameter yang mempengaruhi tinggi rendahnya nilai kapasitas terumbu karang pada suatu kawasan pulau. Untuk keperluan tersebut dilakukan pengukuran terhadap 7 (tujuh) parameter yang berpengaruh pada nilai-nilai kapasitas terumbu karang yang teridiri dari (1) pengukuran indeks dimensi terumbu karang (meliputi panjang dan lebar hamparan terumbu karang yang selanjutnya dikonversi dalam bentuk nilai-indeks dimensi dengan kisaran nilai antara $0,0-1,0 ;$ (2) pengukuran persentasi tutupan karang; (3) dominasi lifeform; (4) Jumlah jenis lifeform; (5) Jumlah spesies ikan karang; (6) kedalaman terumbu karang; dan (7) Jarak ekosistem terumbu karang dari aktivitas manusia atau pemukiman penduduk.

Jumlah spesies karang yang ditemukan pada perairan sekitar pulau Guraici adalah sebanyak 36 spesies dari sekitar 21 genus. spesies-spesies karang tersebut adalah Acropora nobilis, A.formosa, A. gemmifera, A. aspera, A. palifera, Mantipora stellata, Anacropora forbesi,
A.reticulata, Leptoseris explanata, L.hawaiiensis, Oxypora lacera, Pachyseris foliosa, P. speciosa, Astreopora listeri, A. myriophthalma, Favia danae, Favites complanata, F. paraflexuosa, Goniastrea minuta, G. edwardsi, Symphyllia valenciennesi, Pavona minuta, Porites lobata, P. solida, P. lutea, P. cylindrica, Lobophyllia flabelliformes, L.corymbos, Montipora spongodes, Millepora dichotoma, M. platyphylla, Fungia concinna, Pocillopora verrucosa, Goniopora lobata, dan Podabacia crustacea.

\section{Indeks Dimensi Terumbu Karang (IDTK)}

Pengukuran indeks dimensi terumbu karang, bermaanfaat untuk mengetahui luas penyebaran terumbu karang pada suatu pulau. Hasil pengukuran indeks dimensi terumbu karang untuk pulau Guraici, menunjukkan bahwa nilai indeks dimensi sebesar 0,14 tergolong kedalam kategori indeks dimensi "Sangat Rendah".

Berdasarakan pada nilai indeks dan kategori tersebut, menunjukkan bahwa ekosistem terumbu karang pada perairan sekitar pulau Guraici, memiliki hamparan terumbu karang yang sempit dan tersebar tidak merata, kondisi tersebut dapat disebabkan oleh berbagai faktor diantaranya perairan yang terbuka terhadap aktivitas arus dan gelombang sehingga menyebabkan tidak terjadinya penempelan larva terumbu karang ke dasar perairan. Secara umum faktor-faktor pembatas dari kehadiaran ekosistem terumbu karang meliputi cahaya, suhu, salinitas dan sedimen dasar perairan (Supriharyono, 2000).

\section{Persentasi Tutupan Karang}

Berdasarkan hasil analisis yang dilakuan terhadap ekosistem terumbu karang untuk mengetahui persentasi tutupan karang, menunjukkan bahwa nilai persentasi tutupan karang pada Pulau Guraici sebesar 46,82 \% (Coral massif, Other Fauna, Algae).

Sebagaimana penentuan indeks dimensi terumbu karang, nilai persentasi tutupan karang juga ditetukan oleh kehadiran ekosistem terumbu karang pada suatu kawasan pulau. Nilai persentasi tutupan karang di pulau guraici 
tergolong rendah. Persentasi tutupan karang yang semakin tinggi, mengindikasikan tingkat kesehatan dari terumbu karang setempat yang pada gilirannya akan menjamin kelangsungan serta eksistensi ekosistem terumbu karang pada suatu perairan dengan berlangsunya proses regenerasi secara alami.

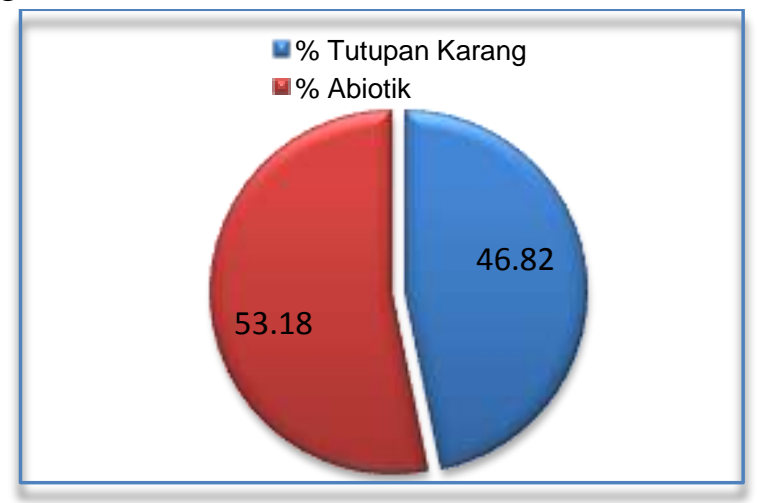

Gambar 4 . Persentasi Tutupan karang hidup dan Abiotik perairan pulau pulau Guraici.

Secara konvensional kondisi terumbu karang dinilai berdasarkan tutupan dan keanekaragaman spesies karang, serta kelimpahan dan keanekaragaman ikan terumbu karang English et al. (1994). Pada perairan-perairan dengan persentasi tutupan karang cenderung kearah sangat rendah dan tidak dapat mempertahankan eksistensinya, maka jika terjadi kondisi yang menguntungkan bagi pertumbuhan makroalga, akan terjadi perubahan strukutur tutupan yang didominasi oleh tutupan makroalga (infasi alga) yang pada gilirannya mematikan karang, hal ini sejalan dengan pendapat Hughes et al. (2006) yang mengemumkakan bahwa ketika terjadi gangguan yang banyak mematikan karang, maka ruang kosong tersebut segera dihuni oleh alga dalam beberapa hari, pergantian dominasi dari komunitas karang ke alga sulit kembali lagi ke karang apabila kelimpahan hewan herbivora rendah karena makroalga tumbuh jauh lebih cepat dari karang, sehingga dapat menghambat kelulusan hidup koloni karang (Lirman 2001).

\section{Dominasi lifeform (bentuk pertumbuhan karang)}

Hasil analisis terhadap parameter dominasi lifeform pada pulau Guraici Acropora brancing (ACB) $(7,94 \%)$, Acropora digitate (ACD) $(1,94)$, Coral brancing (CB) (4,32 \%), Coral foliose (CF) $(5,7 \%)$, Coral massive (CM) (5,82 \%), Caral Mellepora (CME) (2,88 \%), Coral Mushrom (CMR) (1,24\%), Soft coral (CS) (3,06 $\%)$.

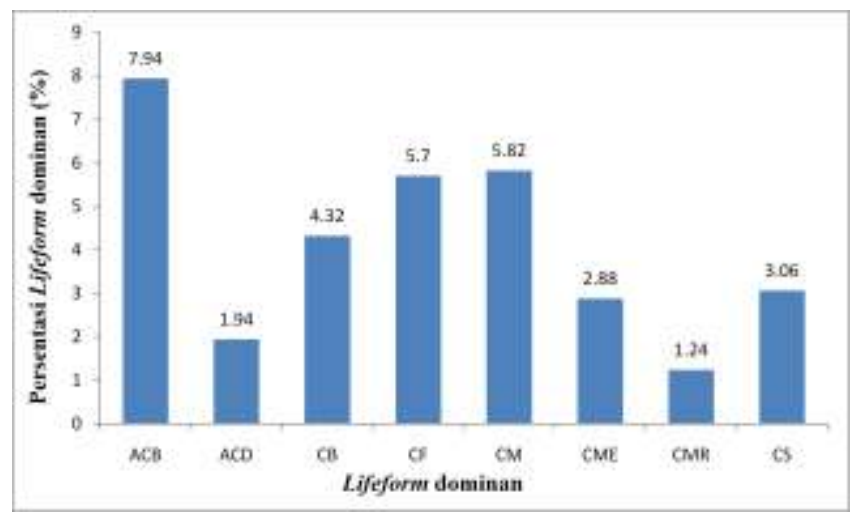

Gambar 5. Dominasi Lifeform di perairan P. Guraici

Dominasi lifeform yang dominan adalah Acropora brancing (ACB) dimungkinkan terjadi karena wilayah pulau Guraici merupakan wilayah yang secara geografis berada relatif jauh terpisah dari daratan pulau besar (mainland) sehingga pengaruh aktivitas ombak sangat berdampak pada pertumbuhan karang.

Karang dari spesies tertentu, genus tertentu, atau dengan bentuk tumbuh tertentu lebih tahan terhadap gangguan daripada yang lainnya dan karang masif atau submasif adalah bentuk tumbuh karang yang lebih tahan terhadap gangguan (Brown \& Suharsono 1990; Gleason 1993; Marshall \& Baird 2000; Ninio \& Meekan 2002). Jenis karang masif secara fisik lebih tahan terhadap hempasan ombak atau gelombang laut sehingga kapasitasnya lebih tinggi, jika diabandingkan dengan bentuk pertumbuhan karang bercabang yang relatif rapuh dan tidak tahan terhadap aksi ombak ataupun gelombang 
yang melewatinya terutama pada perairanperairan dangkal. Walaupun karang masif secara umum lebih tahan terhadap dampak negatif yang ditimbulkan oleh aktivitas alamiah seperti ombak yang disebabkan oleh badai, sebagaimana disampaikan oleh Nybakken (1992) bahwa koloni karang dengan kerangka-kerangka yang padat dan massif dari kalsium karbonat tidak akan rusak oleh gelombang yang kuat. Namun demikian jenis lifeform karang masif umumnya memiliki pertumbuhan yang lambat dibandingkan dengan karang bercabang. Jenis pertumbuhan karang bercabang atau karang daun cenderung memiliki pertumbuhan lebih cepat dari pada karang massif. Karang bercabang dapat mencapai panjang 2-5 $\mathrm{cm}$ per tahun sedangkan karang masif hanya sekitar 0,5-2 cm per tahun (Nybakken 1992).

\section{Jumlah Jenis dan Lifeform}

Sebanyak 16 Jenis karang ditemukan di perairan pulau Guraici, terdiri dari Acropora nobilis, Acropora palifera, Montipora spongodes, Montipora stellata, Oxypora lacera, Pachyseris foliosa, Pachyseris speciosa, Goniastrea minuta , Goniastrea edwardsi, Porites lutea, Millepora dichotoma, Millepora platyphylla, Fungia concinna, Pocillopora verrucosa, Porites cylindrica, Goniopora lobata. Jumlah Jenis lifeform yang ditemukan sebanyak jenis 8 terdiri dari Acropora brancing (ACB), Acropora digitate (ACD), Coral brancing (CB), Coral foliose (CF), Coral massive (CM), Caral Mellepora (CME), Coral Mushrom (CMR), Soft coral (CS). Menurut Englis et al. (1994), secara konvensional terdapat sekitar 13 macam lifeform.

Warisan struktural terumbu karang adalah bentuk tumbuh (lifeform) terumbu karang yang akan bertahan apabila terjadi gangguan. Warisan struktural ini berupa kompleksitas habitat dan substrat yang dapat ditumbuhi oleh karang. Habitat yang kompleks dapat menjaga keanekaragaman ikan dan kelangsungan proses herbivori, meningkatkan rekruitmen karang, sehingga sangat penting dalam pemulihan komunitas karang (Wilson et al. 2007; Lidlie et al. 2007 ; (Peterson et al. 2005).

\section{Jumlah Spesies Ikan Karang}

Hasil penelitian ini menunjukkan bahwa jumlah spesies ikan karang yang ditemukan pada perairan sekitar pulau Guraici sebanyak 49 spesies, yang terdiri dari 29 spesies ikan target, 7 spesies ikan indikator serta 13 spesies ikan Mayor. Spesies yang ditemukan terdiri dari Acanthurus pyroferus, Acanthurus lineatus, Acanthurus thompsoni, Ctenochaetus binotatus, C. tominiensis, Zanclus cornutus, Naso lituratus, Balistapus undulatus, Melichthys vidua, Caesio cuning, Caranx lugubris, Chaetodon kleinii, C. boronesa, $C$. citrinellus, $C$. ulietensis, $C$. ocellicaudus, C. speculum, Heniochus acuminatus, Plectorhinchus diagrammus, Myripristris berndti, Sargocentron caudimaculatus, C. chlorourus, H. melanurus, Hologymnosus doliatus, Labrichthys unilineatus, Lethrinus harak, Monotaxis grandoculis, Lutjanus bohar, L. decussatus, L. fulviflamma, Parupeneus barberinus, $P$. multifasiatus, $P$. indicus, P. cylostomus, P. cylostomus, Scolopsis bilineata, $\quad S$. margaritifer, Pomacanthus navarchus, Abudefduf vaigiensis, Acanthochromis polyacanthus, Amblyglyphidodon curacao, A. leucogaster, Chromis analis, D. trimaculatus, Dischistodus melanotus, S. bicolor, S. bleekri, Cephalopolis argus, C. leopardus, C. urodeta.

Ikan-ikan yang ditemukan saat penelitian ini terdistribusi kedalam 16 family Acanthuridae, $(14,29 \%)$, Balistidae (4,08 \%), Caesionidae (2,04\%), Carangidae (2,04\%), Chaetodontidae (14,29 \%), Haemulidae (2,04\%), Holocentridae (4,08\%), Labridae (8,16\%), Lethrinidae (4,08 $\%)$, Lutjanidae (6,12 \%), Mullidae (8,16\%), Nemipteridae (4,08\%), Pomacanthidae (2,04\%), Pomacentridae (14,29\%), Scaridae (4,08\%), Serranidae $(6,12 \%)$.

Struktur terumbu karang menyediakan habitat bagi ikan-ikan karang. Ikan-ikan herbivora merupakan komponen ekosistem yang 
penting dalam menentukan arah suksesi terumbu karang (Bellwood et al. 2004).

Pada perairan dengan kondisi ekosistem terumbu karang dalam keadaan baik umumnya memiliki spesies ikan karang yang relatif berlimpah baik ikan-ikan yang tergolong sebagai ikan target, ikan mayor maupun ikan indikator, keadaan tersebut merupakan keadaan ideal, dalam arti tidak terjadi gangguan berlebihan khususnya yang ditimbulkan oleh aktivitas manusia yaitu adanya aktivitas penangkapan yang berlebihan dan destruktif. Keberadaan ikan-ikan yang hidup di kawasan ekosistem terumbu karang turut berperan penting dalam menjaga keseimbangan dan kelestarian ekosistem terumbu karang karang.

\section{Kedalaman Terumbu Karang}

Kedalaman terumbu karang adalah salah satu parameter yang digunakan untuk mengukur kapasitas ekosistem terumbu karang. Ekosistem terumbu karang umumnya ditemukan pada perairan dengan kedalaman hingga $25 \mathrm{~m}$, atau sangat tergantung pada seberapa jauh intensitas cahaya matahari menembus dasar perairan. Hamparan ekosistem terumbu karang yang ditemukan di perairan pulau Guraici ditemukan pada kedalam antara 0,5-10 meter. Cahaya metahari merupakan salah satu parameter penting yang berpengaruh dalam pembentukan terumbu karang. Menurut Thamrin (2006) bahwa karang hermatipik dapat ditemukan dari daerah permukaan atau dari daerah intertidal sampai kedalaman 70 meter, akan tetapi pada umumnya ditemukan sampai kedalaman 50 meter, namun demikian sebagian besar hidup dengan subur sampai pada kedalaman 20 meter, dan lebih rinci lagi keanekaragaman spesies dan pertumbuhan terbaik ditemukan pada kedalaman antara 3-10 meter.

Faktor kedalaman tersebut sangat berpengaruh terhadap hewan karang berhubungan dengan intensitas cahaya yang masuk kedalam perairan. Cahaya yang masuk kedalam perairan sangat dibutuhkan oleh simbion karang zooxanthellae sebagai penyuplai utama kebutuhan karang sebagai inang (Thamrin, 2006). Penetrasi cayaha matahari akan merangsang terjadi proses fotosintesis oleh zooxanthellae simbiotik dalam jaringan karang. Tanpa cahaya yang cukup laju fotosintesis akan berkurang, dan secara bersamaan kemampuan karang untuk membentuk terumbu $\left(\mathrm{CaCO}_{3}\right)$ akan berkurang pula. Pertumbuhan karang akan sangat berkurang saat tingkat laju produksi primer sama dengan respirasinya (zona kompensasi) yaitu suatu kedalaan terjadinya kondisi intensitas cahaya matahari berkurang sekitar 15\%-20\% dari intensitas cahaya di permukaan (Dahuri 2003).

\section{Jarak Ekosistem Terumbu Karang Dari Pemukiman Penduduk}

Jarak suatu ekosistem pesisir seperti ekositem terumbu karang dari aktivitas manusia atau pemukiman penduduk penting untuk ditelaah, karena semakin dekat suatu sumberdaya dengan aktivitas manusia maka sumberdaya tersebut semakin rentan, sebaliknya semakin jauh atau semakin terisolasi suatu sumberdaya dari manusia maka sumberdaya tersebut akan semakin terjaga, (Algar et al. 2002). Selain itu Dahuri (2003) menyampaikan bahwa ekosistem terumbu karang merupakan suatu ekosistem yang sangat rentan terhadap gangguan akibat kegiatan manusia dan pemulihannya memerlukan waktu yang relatif lama. Berdasarkan hasil penelitian ini, ekosistem pesisir yang tedapat pada pulau Guraici berjarak antara 500 meter dari pemukiman penduduk di pulau Lelei.

\subsubsection{Kapasitas Adaptif Ekosistem Terumbu Karang}

Berdasarkan pada analisis yang dilakukan terhadap setiap parameter untuk menilai kapasitas adaptif ekosistem terumbu karang maka diperoleh hasil pengukuran nilai kapasitas terumbu karang pada pulau Guraici yaitu $\operatorname{KAETK}(0,37)$. Nilai tergolong pada kategori kapasitas "rendah". Secara rinci hasil pengukuran dan analisis serta distribusi nilai maupun kategori kapasitas adaptif ekosistem terumbu karang di pulau pulau Guraici ditampilkan pada tabel berikut. 
Tabel 7. Hasil Pengukuran dan Analisis Parameter serta Distribusi Nilai Kapasitas Adaptif Ekosistem Terumbu Karang di pulau Guraici.

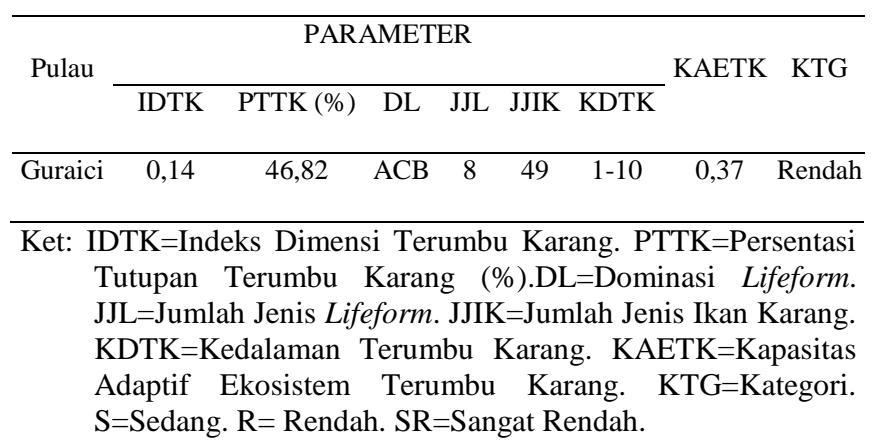

Tinggi atau rendahnya kapasitas adaptif ekosistem terumbu karang pada suatu perairan sangat ditentukan oleh faktor-faktor yang diteliti dalam penelitian ini sebagaimana yang telah diuraikan sebelumnya. Faktor luas dan penyebaran terumbu karang yang membentuk indeks dimensi terumbu karang, faktor persentasi tutupan karang dan faktor dominasi lifeform adalah tiga faktor yang sangat berpengaruh pada tinggi rendahnya kapasitas ekosistem terumbu karang, selanjutnya diikuti oleh faktor jumlah jenis lifeform, jumlah spesies ikan karang, kedalaman terumbu karang serta jarak dari aktivitas manusia atau pemukiman penduduk. Semakin tinggi nilai faktor-faktor tersebut, maka akan semakin tinggi kapasitas ekosistem terumbu karang pada suatu pulau dan sebaliknya.

Pulau. Guraici, hal ini dipengaruhi oleh peranan parameter penting yang terlong sangat rendah seperti parameter indeks dimensi yang mengindikasikan luas serta penyebaran ekosistem terumbu karang dan parameter dominasi lifeform yang didominasi oleh karang bercabang (coral brancing) maupun parameter-parameter lainnya yang tergolong tergolong sedang dan rendah, sehingga memberikan kontribusi yang besar terhadap tinggi atau rendahnya kapasitas adaptif ekosistem terumbu karang pada perairan sekitar pulau-pulau tersebut.

\subsubsection{Kapasitas Adaptif Ekosistem Mangrove}

Pengukuran yang dilakukan untuk mengetahui nilai kapasitas ekosistem mangrove pulau Guraici dilakukan dengan mengukur enam (6) parameter yang diasumsikan mempengaruhi tinggi atau rendahnya kapasitas ekosistem mangrove tersebut. Parameter-parameter tersebut adalah (1) pengukuran indeks dimensi, (2) mengidentifikasi spesies mangrove dominan pada setiap pulau, (3) menghitung kerapatan pohon mangrove per hektar, (4) menghitung jumlah genera, (5) mengamati tipe substrat tumbuhnya mangrove, (6). Mengukur jarak ekosistem mangrove dari aktivitas manusia atau pemukiman penduduk.

Dalam penelitian ini, ekosistem mangrove di pulau Guraici tidak ditemukan, sehingga perhitungan dan analisis terhadap kapasistas adaptif ekosistem mangrove bernilai nol (0). Mangrove yang tidak tumbuh di pulau Guraici disebabkan oleh berbagai faktor diantaranya substrat dasar yang hanya terdiri dari pasir halus, perairan yang relatif berarus. Dahuri (2003) ; Bengen (2004) menyatakan bahwa mangrove dapat ditemukan pada perairan yang landai dengan distribusi sedimen yang stabil . Sedangkan pulau Guraici secara umum memiliki pantai yang relatif terbuka terhadap aksi gelombang ataupun obak serta arus sehigga menyebabkan ketidakstabilan pada substrat dasar perairan serta menyebabkan buah mangrove sebagai bakal bibit hanyut terbawa gelombang serta arus air laut, hal ini sejalan dengan pendapat yang dikemukakan oleh Dahuri (2003) bahwa mangrove hanya dapat dijumpai pada wilayah pesisir yang terlindung dari gempuran ombak.

\subsubsection{Kapasitas Adaptif Ekosistem Padang Lamun (seagrass)}

Sebagaimana pengukuran kapasitas adaptif pada ekosistem terumbu karang serta ekosistem mangrove, pengukuran pada ekosistem padang lamun dilakukan dengan mengukur 6 (enam) parameter meliputi (1) pengukuran indeks dimensi ekosistem padang lamun meliputi 
dimensi lebar dan dimensi panjang yang selanjutnya dikonversi dalam bentuk nilai indeks dimensi dengan kisaran nilai antara 0,0-2,0, (2) mengidentifikasi spesies lamun dominan, (3) menghitung persentasi tutupan, (4) menghitung jumlah spesies lamun, (5) mengamati tipe substrat tumbuh lamun, (6) megukur jarak ekosistem lamun dari aktivitas manusia atau pemukiman penduduk.

Perairan disekitar pulau Guraici, tidak ditemukan ekosistem padang lamun, sehingga nilai kapasitas adaptif ekosistem lamun untuk pulau Guraici nol (0). Hasil pengamatan terhadap tipe substrat dasar perairan di pulau ini terdiri dari pasir halus dan pecahan karang, salin itu perairan sekitarnya relaftif berarus. Dahuri (2003) menjelaskan bahwa padang lamun dapat hidup pada berbagai tipe substrat mulai dari lumpur sampai sedimen dasar yang terdiri dari endapan lumpur halus sekitar $40 \%$. Kedalaman substrat berperan dalam menjaga stabilitas sedimen yang mencakup 2 hal, yaitu pelindung tanaman dari arus air laut, dan tempat pengolahan serta pemasok nutrien. Kedalaman sedimen yang cukup merupakan kebutuhan utama untuk pertumbuhan dan perkembangan habitat lamun.

Lamun biasanya ditemukan tumbuh subur di daerah terbuka pasang surut dan perairan pantai atau gobah yang dasarnya berupa lumpur, pasir, kerikil maupun patahan karang mati dengan kedalaman sampai 4 meter, pada perairan yang sangat jernih, lamun dapat ditemukan tumbuh pada kedalaman antara 8-15 meter (Den Hartog 1970).

Pada daerah terjadinya bioturbasi yang tinggi akibat aktivitas organisme bentik seperti udang, moluska serta cacing, kepadatan populasi dan spesies pionir cenderung berkurang. Jika dibandingkan dengan padang lamun yang hidup pada sedimen berkarbonat yang berasal dari patahan terumbu karang, padang lamun yang tumbuh di sedimen yang berasal dari daratan lebih dipengaruhi oleh faktor run of daratan yang berkaitan dengan kekeruhan, suplai nutrien pada musim hujan serta fluktuasi salinitas (Erftemeijer 1993 in Dahuri 2003).

\subsection{Kerentanan Pulau Guraici}

Hasil analisis yang dilakukan terhadap komponen ekosistem pesisir untuk menilai kerentanan pulau Guraici menunjukkan nilai indeks kapasitas Adaptif sebesar 0,37, dengan kategori "sangat rendah", yang berarati bahwa pulau Guraici memiliki kerentanan sangat tinggi. Nilai Kapasitas adaptif ekosistem pesisir yang rendah tersebut disebabkan karena hanya ditemukan ekosistem terumbu karang di perairan sekitar pula tersebut, sedangkan ekosistem mangrove dan lamun tidak ditemukan.

Rendahnya kapasitas adaptif pulau Guraici, sangat berdampak pada berkurangnya luas daratan pulau tersebut, saat ini luas daratan pulau Guraici telah berkurang secara drastis karena terjadinya aberasi. Hasil analisis dalam penelitian ini, menunjukkan bahwa luas daratan pulau Guraici sekitar 0,59 hektar (ha). Menurut DPK-Malut, luas daratan pulau Guraici pada tahun 2004 seluas 1,6 ha, sehingga jika dibandingkan hingga saat ini luas daratan pulau Guraici telah berkurang sekitar 1,1 ha. kondisi ini dapat terjadi karena disekitar pulau tersebut hanya ditemukan ekosistem terumbu karang dalam luasan yang sempit sehingga tidak memberikan pengaruh yang signifikan terhadap peningkatan kapasitas adaptif pulau Guraici dalam menghadapi ancaman gelombang serta arus air laut yang menuju pesisir maupun daratan pulau, sedangkan ekosistem mangrove serta ekosistem padang lamun yang secara ekologi berfungsi sebagai pelindung pantai maupun daratan pulau dari aberasi, menstabilkan sedimen, mengurangi kecepatan gelombang serta arus air laut yang akan memasuki garis pantai serta daratan pulau tidak ditemukan tumbuh disekitar pulau Guraici, hal ini memeberikan kontribusi yang sangat tinggi terhadap rendahnya kapasitas adaptif pulau tersebut sehingga kemampuan untuk menyesuaikan diri terhadap suatu 
gangguan ataupun tekanan serta potensi kerusakan sangat rendah, dengan demikian dapat dikatakan bahwa pulau Guraici adalah pulau yang sangat rentan sebagai akibat rendahnya kapasitas adaptif ekosistem pesisir di sekitarnya.

Usaha yang dapat dilakukan untuk meningkatkan kapasitas adaptif pulau Guraici saat ini adalah dengan melakukan rehabilitasi (penanaman mangrove dan lamun) disekitar pulau tersebut sehingga dalam jangka panjang dapat menurunkan kerentanan pulau Guraici. Subur (2012) menyatakan bahwa semakin tinggi kapasitas yang dimiliki oleh setiap ekosistem pesisir, akan memberikan kontribusi yang besar terhadap tingginya kapasitas adaptif suatu pulau, dan sebaliknya apabila semakin rendah kapasitas setiap ekosistem yang dimiliki oleh suatu pulau, maka akan semakin rendah kapasitas adaptif ekologi dari pulau tersebut, sehingga akan meningkatkan keretanan suatu pulau kecil.

Luers (2005) menjelaskan bahwa Kapasitas adaptif memiliki potensi untuk menggeser posisi sistem pada permukaan kerentanan tinggi ke kerentanan yang lebih rendah dengan mengurangi sensitivitas (sensitivity) dan keterbukaan (exposure).

\section{DAFTAR PUSTAKA}

Algar DA, AA Burbidge, GJ Angus. 2002: Cat eradication on Hermite Island, Montebello Islands, Western Australia. In: Turning the tide: the eradication of island invasive species. CR Veitch and MN Clout (eds.), IUCN SSC Invasive Species Specialist Group, IUCN, Gland, pp. 14-18.

Briguglio L. 1995. Small Island Developing States and Their Economic Vulnerabilities. J. World Develop. 23: 1615-1632.

Bunce M, L Mee, LD Rodwell, R Gibb. 2009. Collapse and Recovery in a Remote Small Island - A Tale of Adaptive Cycle or Downward Spirals ?. J. Glo. Environ. Cha. 19: 213-226.

Brookfield HC. 1990. An Approach to Island. In Beller et al. Sutainable Development and
Environment Managemen of Small Islands. Unesco. Paris.

Bengen DG. 2004. Ekosistem dan Sumberdaya Alam Pesisir dan Laut serta Prinsip Pengelolaannya. sinopis. PKSPL-IPB. Bogor.

Beller W. 1990. How to Sustain Small Island. In Beller,d'Ayala and Hein (eds). Sustainable Development and Environmental Management of Small Island. Unesco. Paris.

Brooks N. 2003. Vulnerability, Risk and Adaptation: A Conceptual Framework. Centre for Climate Change Research. University of East Anglia, Norwich.

Brown B, Suharsono. 1990. Damage and recovery of coral reefs affected by $\mathrm{El}$ Nino related seawater warming in the Thousand Islands, Indonesia. J. Coral Reefs 8:163-170.

Bellwood DR, Hughes TP, Folke C, Nyström M. 2004. Confronting the coral reef crisis. J. Nat. 429:827-833

Bengen DG. 2004. Ekosistem dan Sumberdaya Alam Pesisir dan Laut serta Prinsip Pengelolaannya. sinopis. PKSPL-IPB. Bogor.

[DKP] Departemen Kelautan dan Perikanan. 2001. Pedoman Umum Pengelolaan Pulau-Pulau Kecil yang berkelanjutan dan berbasis masyarakat. Ditjen Pesisir dan Pulau-Pulau Kecil. Jakarta.

[DKP] Departemen Kelautan dan Perikanan. 2002. Keputusan Menteri Kelautan dan Perikanan No. 34 tahun 2002 Tentang Pedoman Umum Penataan Ruang Pesisir dan Pulau-Pulau Kecil. Departemen Kelautan dan Perikanan. Jakarta.

[DKP] Departemen Kelautan dan Perikanan. 2004. Profil Pulau-Pulau Kecil di Indonesia. Jilid 1. Direktorat Jenderal Pesisir dan Pulau-Pulau Kecil. Jakarta. 104 hal.

Dahuri R. 2003. Keanekaragaman Hayati Laut: Aset Pembangunan Berkelanjutan Indonesia. Gramedia Pustaka Utama. Jakarta.

Duokakis E. 2005. Costal vulnerability and risk parameter. J. Europ. Water 11/12: 3-7.

English S, C Wilkinson and V Baker. 1997. Survey Manuar For Tropical Marine Recources. 
Second edtion. Australian Institute of Marine Science. Australia.

Gossling S. 1999. Ecotourism: a means to safeguard biodiversity and ecosystem function ?. $J$. Ecol. Econ. 29: 303-320.

Griffith and Inniss. 1992. Small Island Characteristics dan Their Constrain of Sustainable Development.

Gallopin GC. 2006. Linkages between vulnerability, resiliensi, and adaptive capacity. J. Global Environ. Change. 16:293-303.

Gunderson L and CS Holling. 2002. Panarchy: Understanding Transformations in Human and Natural Systems. eds. Island Press, Washington, D.C.

Gleason MG. 1993. Effects of disturbance on coral communities: bleaching in Moorea, French Polynesia. J. Coral Reefs 12:193 201.

Hulme M. 2002. What is Adaptation? Personal communication. Nrwich, UK, Tyndall Centre For Climate Research, University of East Angelia.

Hughes TP, Bellwood DR, Folke CS, McCook LJ and Pandolfi JM. 2006. No-Take Areas, herbivory and coral reef resilience. TRENDS in Ecology and Evolution 22: 1-3.

Lirman D. 2001. Competition between macroalgae and corals: Effects of herbivore exclusion and increased algae biomass on coral survivorship and grouwth. J. Coral Reefs 19:392-399.

Ledlie MH, Graham NAJ, Bythell JC, Wilson SK, Jennings S, Polunin NVC, Hardcastle J. 2007. Phase shifts and the role of herbivory in the resilience of coral reefs. J.Coral Reefs 26:641-653.

Lewis J. 2009. An Island Characteristic: Derivated Vulnerabilities to Indigenous and Exogenous Hazard. Shima: J. of Res. into Island Cult. Vol. 3 No. 1.

Mimura N. 1999. Vulnerability of Island Countries in the South Pacific to Sea Level Rise and Climate Change. J. Climate cha. res. Vol.12.

Marshall PA, Baird AH. 2000. Bleaching of corals on the Great Barrier Reef:differential susceptibilities among taxa. J. Coral Reefs 19:155-163.

Ninio R, Meekan MG. 2002. Spatial patterns in benthic communities and the dynamics of a mosaic ecosystem on the Great Barrier Reef, Australia. J. Coral Reefs 21:95-103.

Nybakken JW. 1992. Biologi Laut. Suatu Pendekatan Ekologi. PT. Gramedia. Jakarta.

Peterson G, Allen CR, Holling CS. 1998. Ecological resilience, biodiversity, and Scale. J. Ecosys. 1: 6-18.

Rosenzweig ML. 1995. Species Diversity in Space and Time. Cambridge University Press, Cambridge, 436 pp.

[RI] Republik Indonesia. 2007. Undang-Undang No. 27 Tahun 2007 Tangang Pengelolaan Wilayah Pesisir Dan Pulau-Pulau Kecil. Jakarta.

Smith K, Barrett CB, Box PW. 2000. Participatory risk mapping for targeting research and assistance: with an example from East African pastoralists. J. World Develop. 28: 19451959.

Smit B, Pilifosofa O. 2003. From Adaptation to Adaptive Capacity and Vulnerability Reduction, in: Smith, J.B., Klein, R.J.T., Hug, S. (eds), Climate Change, Adaptive Capacity and Development. Imperial College Press. London.

[SOPAC] South of Pacific Islands Applied Geoscience Commission. 2005. Environmental Vulnerability Index: EVI: Description of Indicators. UNEP-SOPAC.

Subur R. 2012. Daya Dukung Ekowisata Dengan Pendekatan Kapasitas Adaptif Ekologi Di Pulau-Pulau Kecil (Kasus Gugus Pulau Guraici Kabupaten Halmahera Selatan, Propinsi Maluku Utara). [disertasi]. Sekolah Pascasarjana Institut Pertanian Bogor. Bogor.

Subur R. 2013. Kapasitas Adaptif Ekologis Gugus Pulau Guraici Kecamatan Kayoa, Kabupaten Halmahera Selatan, Provinsi Maluku Utara. J. Marine Fisheries. IPB. 
Bogor. Vol, 4, No, 2. Nov. 2013. Hal. 97 sd. 108.

Subur R. 2011. Kapasitas Adaptif Ekosistem Lamun (Seagrass) di Gugusan Pulau Guraici Kabupaten Halmahera Selatan. J. Agrisains. Universitas Tadulako. Vol. 12. H No. 3. Hal. 207-215.

Thamrin. 2006. Karang: Biologi reproduksi dan ekologi. Minamandiri Press. Pekanbaru.
[UN] United Nation . 2007. Oceans and law of the sea. Division for Ocean Affairs and the Law of the Sea, Office of Legal Affairs. United Nations.

Vicente L. 1999: Evolutionary strategies on insular environments. J. Nat. Croatica 8 (3): 301323.

Wilson SK, Graham NAJ, Polunin NVC. 2007. Appraisal of visual assessments of habitat complexity and benthic composition on coral reefs. J. Mar Biol. 151:1069-1076. 